\title{
Criminal Sanctions against Taxpayer Who are Negligent to Register Land and Building Taxes
}

\author{
Made Putri Pradnya Parahita, Simon Nahak and I Ketut Widia \\ Program Magister IImu Hukum, Universitas Warmadewa-Denpasar \\ *email: putripradnya96@gmail.com
}

\begin{tabular}{|l|}
\hline How to cite (in APA style): \\
Parahita, M, P, P., Nahak, S., Widia, I, K. (2020). Criminal Sanctions against Taxpayer Who are Negligent to Register \\
Land and Building Taxes. Jurnal Hukum Prasada, 7(2), 73-78. doi: https://doi.org/10.22225/jhp.7.2.1089.73-78
\end{tabular}

\begin{abstract}
One of the most common problems related to land and building tax is where there are citizens who are aware of their obligation to pay taxes by registering their objects, but due to certain circumstances, the taxpayer does not register the tax object he owns. This study aims to find out the regulation of criminal sanctions against taxpayers who do not register land and building tax and to find out the criminal liability of taxpayers who do not register the object of land and building tax. This study uses normative research that starts with an indication of the obscurity of legal norms. The results of this study showed that the provision of sanctions is needed as a form of the last effort to realize the certainty of tax activities going well. Sanctions given can be in the form of administrative sanctions in the form of fines to criminal sanctions in the form of prison or confinement, which can be imposed on taxpayers and related officials. Criminal liability in the field of taxation arises when each taxpayer is indicated to have committed a tax crime. The intended taxpayer is an individual taxpayer or legal entity or corporation. Likewise, it has been regulated that starting from the taxpayer, tax officials/employees, to third parties have their respective criminal liabilities. The legal basis is Law Number 28 of 2007 concerning General Provisions and Tax Procedures. The advice given is the need for strict rules regarding criminal sanctions against land and building tax registration.
\end{abstract}

Keywords: Land and Building Tax; Sanctions; Taxes; Taxpayers

\section{INTRODUCTION}

In Indonesia, the lives of the people and the economy are largely agrarian, based on the 1945 Constitution Article 33 Paragraph 3 states:

"Earth and water and the natural wealth contained in them are controlled by the State and are used for the greatest prosperity of the people." Every Indonesian citizen must pay taxes.

Fulfilling obligations in paying taxes will have an impact on fulfilling the objectives of the State of Indonesia. The government has ratified Law Number 28 of 2009 concerning Regional Taxes and Regional Levies. The emergence of this Act supersedes the old Law namely Law Number 18 Year 1997 and Law Number 34 Year 2000 concerning Regional Taxes and Regional Retributions. Article 2 of Law Number 28 of 2009 concerning Regional Taxes and Regional Retributions, states:

Regional taxes are divided into two types, namely types of provincial taxes and types of district/city taxes. This division is carried out in accordance with the authority of imposition and collection of each type of regional tax in the administrative area of the province or district/city concerned. Taxes managed by provinces and districts/cities include:

The type of provincial tax consists of: 
Vehicle tax;

Transfer fees for motor vehicle names;

Motor vehicle fuel tax;

Surface water tax;

Cigarette tax.

The type of district/city tax consists of:

Hotel tax;

Restaurant tax;

Entertainment tax;

Advertisement tax;

Street lighting tax;

Taxes on non-metallic minerals and rocks;

Parking tax;

Groundwater Tax;

Bird nest wallet tax;

Rural and urban land and building tax; and

Fees for acquiring land and building rights."

Public awareness in paying taxes becomes a very important factor, this is because the tax collection system that applies in Indonesia is a Self Assessment System, wherein this system all fulfilment of tax obligations is carried out entirely by the taxpayer himself, tax authorities (tax collectors) only do supervision through inspection procedures, (Devano \& Rahayu, 2006).

The problem that is often encountered related to this UN Tax is where there are citizens who are already aware of their obligation to pay taxes by registering the object they have in order to have the Tax Object Number which is issued SPPT annually, but due to certain circumstances the taxpayer does not fulfil his obligation to pay taxes Earth and Urban-Rural Buildings are subject to administrative sanctions in the form of fines, but in conditions where there are citizens who have a tax object due to a situation both intentionally and unintentionally not registering the tax object that is owned so that the citizens of that country do not have a UN Tax Object Number (NOP) and each year does not get an SPPT PBB, this makes it as if the citizens do not have a tax obligation on land objects that must be fulfilled until at one time the object of the tax is registered.

Acts of legal awareness carried out by citizens who have registered their tax objects are not given appreciation so that there is an imbalance between the implementation of guaranteeing the rights and obligations of citizens who should be guaranteed in the rule of law. Based on the 1945 Constitution Article 27 paragraph (1) states that all citizens together with their position in the law. Equality before the law means that every citizen must be treated fairly both juridically and by law enforcement officials and the government as the recipient of the mandate for the implementation of the law, so that according to the description above there is vagueness of norms that have not been regulated so that a paper entitled "Penal Sanctions is drawn up" Against taxpayers who are negligent in registering land and building taxes."

Some similar studies have been conducted previously by some researcher, such as Kusumo (2009) which conducted a study about "Legal Sanctions in the Taxation Sector". The results of this study showed that law sanctions in taxation consist of administrative and penal sanction. However, the administrative one is preferred in its implementation. It is because of its more advantage in term of time and the penal money goes to the state cash. The disadvantageous is it does not give up giving to its doers and who will do it. Moreover, Wibowo (2009) also conducted a similar study entitled "The Effectiveness of Tax Criminal Sanctions in Law Number 28 of 2007 concerning General Provisions and Tax Procedures". The results of this showed that applying of sanction in the case of manipulating of tax is not 
yet effective, because not all that order in the norm did, for example, bookkeeping's not true and not yet had Taxpayer Identification Number. Therefore, the policy formulation of criminal sanctions in Law Taxation and also there must be support society and from government enforcers, so the application of sanction of crime in the taxation area can effectively do it.

Thus, based on the background and the latest elated study above, this study aims to find out the regulation of criminal sanctions on taxpayers who do not register their land and building tax and to find out the criminal liability for taxpayers who do not register the land and building tax object.

\section{METHOD}

This study is normative legal research. Normative legal research which is carried out by examining existing legal norms which are sourced from the regulations governing Indonesian taxation regulations, so this study used secondary materials or library materials. Moreover, the approach used in this study is a regulatory approach and also a conceptual approach.

\section{DISCUSSION}

\section{Arrangement of Criminal Sanctions Against Taxpayers Who Are Negligent to Register Land and Building Taxes}

Self Assessment System is a taxation system that applies in Indonesia. The enactment of this system gives full trust to taxpayers to report and register their own tax. The tax sanctions can be administrative and criminal. Taxation criminal law means an act that violates the prohibitions or obligations specified in tax laws, which cause a financial loss to the State where the perpetrator of the tax crime can be threatened with criminal penalties, (Bohari, 2004).

Criminal law is basically due to violations and crime. So that in taxation, violations are called negligence, namely inadvertent, negligent, not careful in fulfilling tax obligations so that it can cause losses to the State's income. The imposition of tax criminal sanctions aims to make taxpayers more compliant with tax rules and deter violators of tax regulations. This criminal tax penalty can arise due to several types of causes as follows:

Taxpayers who do not deliver SPTs (Notifications) or taxpayers submit tax returns but falsify documents or fill in incorrect data.

Taxpayers who intentionally do not report SPT.

Refuse to be examined by a tax official.

Does not hold proper bookkeeping.

Self Assessment System, where the tax registers, pay and report their own taxes. Providing a large responsibility for voluntary compliance. Voluntary compliance related to Self Assessment applied has the potential that can be violated, namely:

Tax Avoidance, a transaction scheme that is aimed at minimizing the tax burden by registering weaknesses or utilizing legal loopholes. The characteristics of tax avoidance are trying to minimize the tax burden.

Tax Darkening is an effort to tax smuggling, which is a tax scheme that is owed by violating tax provisions, for example not reporting part of sales, collecting taxes but not depositing them.

The enactment of Law Number 28 of 2009 concerning Taxes and Regional Retributions, the Land and Building Tax which used to be a central tax, now the collection authority is in the Regency/City area. Land and Building Tax is a levy on land and building that arises because of a profit or socio-economic position for a person or entity that has a right to it, or benefits from it, (https://www.online-pajak.com/pajak-bumi-dan-bangunan).

Law concerning Regional Taxes and Regional Retributions Number 28 of 2009 is a collection and collection of land and building tax carried out by Regency/City Governments 
in Indonesia. Thus, the application of Law Number 28 of 2009 concerning Regional Taxes and Regional Retributions must be ratification that is carried out perfectly, this is intended so that the existing regulations below are in line with the rules above.

The Denpasar city government, in particular, has a regional regulation on Land and Building Tax, which is regulated in a Regional Regulation Number 4 of 2012 concerning Land and Rural and Urban Land Taxes. Those who are subject to Taxes in Land and Building Taxes are individuals and bodies that have rights to the earth, benefit from the earth, own buildings, control buildings and obtain benefits for buildings.

As the legal basis of UN Tax, Law No. 28 of 2009 concerning Regional Taxes and Regional Retributions in Chapter XVI also regulates Criminal provisions, namely in Article 174 to Article 178. Based on Lawrence M. Friedman's Law System Theory, the success of law enforcement depends on 3 legal systems, namely legal structure, a legal substance, and legal culture. If examined from the legal substance, the rules regarding Land and Building Tax have been regulated in Law Number 12 of 1994 concerning Amendment to Law Number 12 of 1985 concerning Land and Building Taxes. Since the enactment of Law Number 28 of 2009 concerning Regional Taxes and Regional Retributions, the authority to collect land and building taxes is submitted to the district or city government.

Regulations concerning criminal sanctions for taxpayers who fail to register land and building taxes have not been explicitly regulated in the Regional Regulation of Denpasar City Number 4 of 2012 concerning Rural and Urban Land and Building Taxes, criminal sanctions are only imposed on persons or entities that carry out chartering collecting land and building taxes. This is stipulated in the criminal provisions of Article 23 paragraph 1 which state:

"Every person or body that violates the provisions of Article 12 paragraph 1 is threatened with a maximum sentence of 6 (six) months imprisonment or a maximum fine of Rp.50,000,000 (fifty million rupiahs)."

Then in Article 12 paragraph 1 states:

"Rural and urban land and building tax collection are prohibited from being bought."

When linked to the legal structure, the authority of law enforcement agencies related to land and building tax has been regulated. The government institution that manages state taxation in Indonesia is the Directorate General of Taxes, which is one of the directorates general under the auspices of the Ministry of Finance of the Republic of Indonesia. Then associated with the culture of law, is the embodiment of the attitudes of the community, beliefs, values adopted by the community and their ideas or expectations of the law and system of law. Very closely related to legal awareness of the obligation to register and pay for land and building taxes.

\section{Criminal Liability For Taxpayers Who Do Not Register Land and Building Taxes}

Making tax payments is an obligation of all citizens, except for those who are freed by legislation. Because of its compelling nature, the State imposes sanctions on taxpayers who do not pay taxes.

Sanctions can be imposed if the taxpayer does not return the Tax Object Notification Letter or if the taxpayer does not fill the Tax Object Notification Letter (SPOP) clearly, correctly and completely. The criminal sanction that can be imposed on the taxpayer is that if a person with negligence does not return a Tax Return Notification Letter (SPOP) or incorrectly filed the Tax Object Notice, which could cause state losses, this could be threatened with imprisonment for a maximum of 6 (six) months or a fine of at most 2 (two) times the tax owed.

As a form of justice in the field of taxation, namely the balance between the rights of the State and the rights of citizens as taxpayers, then the law has been regulated regarding the rights and obligations of taxpayers. The obligation here is the obligation to register as a taxpayer, withholding or collecting taxes, and paying taxes. One of the types of tax that is a liability for citizens, namely Land and Building Tax. This tax arises because of a profit or socio-economic position for a person or entity that has a right over it, or benefits from the 
earth or building.

Payment of land and building tax is based on SPPT issued annually which currently in accordance with Law No. 28 of 2009 concerning Regional Taxes and Retributions has become the authority of the district/city government. With the Indonesian taxation system that adheres to self-assessment, the system imposes or requires every person who has a tax object to report and register the tax object himself in order to have a tax identity in the PBB tax referred to as NOP. This inherent obligation is often overlooked by individuals who, for reasons of ignorance of legislation or deliberately not registering tax objects whose purpose is to avoid payment of PBB taxes.

From the registration process to the payment of land and building tax, it is a civic obligation that must be fulfilled by every citizen who owns the tax object. This is based on the fact that the tax has a nature that can be forced. That is, if the tax is not paid, it can cause a result. This nature of being forced must be carried out considering that tax payments do not receive remuneration directly, such as retribution, and the payment is intended for the public interest.

Criminal sanctions are types of sanctions that are malicious that can be threatened or imposed on acts or perpetrators of criminal acts or crimes that can disturb or endanger legal interests, (Andrisman, 2009). Criminal sanctions are a guarantor for rehabilitating the behaviour of the perpetrators of these crimes, but not infrequently criminal sanctions are created as a threat from human freedom itself, (Chazawi, 2011).

Every person who commits a crime or is against the law, as formulated in the law, the person should be accountable for the deed according to his mistake. Someone is said to have an error when at the time of doing an action seen in terms of society shows a normative view of the mistakes that have been made by that person, (Arief, 2001).

Roeslan Saleh explained that people who are capable of criminal responsibility must have 3 (three conditions) as follows: (Andrisman, 2009).

Can realize the meaning of his actions;

Can realize that the act cannot be deemed appropriate in community relations;

Able to determine his intention or will in doing his actions.

Sanctions can be imposed if the taxpayer does not return the Tax Object notification or if the taxpayer does not complete the Tax Object Notification letter clearly, correctly and completely. The criminal sanctions that can be imposed on the taxpayers are if someone with a default does not return the SPOP or fills out the SPOP incorrectly, which can cause State losses.

Regarding criminal sanctions, it cannot be separated from criminal liability. Legal subjects who can be held responsible for violations of tax criminal law and can be sentenced to criminal penalties are subject to tax crime, namely taxpayers who commit criminal acts, including people representing taxpayers in carrying out tax obligations, officials or officials of tax administration or state administrators in tax collection matters and third parties.

Taxpayers who are negligent in registering land and building taxes are one of the violations in the field of taxation. Although this often only reaches the process of granting administrative sanctions and fines, it is not impossible to potentially be subject to criminal penalties as stipulated in the provisions of the Act. This is done in view of the fact that criminal acts in the field of taxation are carried out by taxpayers by means of avoidance of collection or manipulation of tax reports.

\section{CONCLUSION}

Based on the results obtained, thus it can be concluded: 1) Regulations regarding sanctions against tax criminal acts are regulated in the Regional Retribution Act. But in the Regional Regulation of Denpasar City Number 4 of 2012 concerning Rural and Urban Land and Building Taxes as implementing regulations of the Act, it does not regulate criminal provisions for taxpayers who fail to register their land and building taxes, giving rise to the 
impression that regulations it is not strict and does not require taxpayers to register their tax objects. 2) Criminal liability in the field of taxation arises when each taxpayer is indicated to have committed a tax crime. The taxpayer is an individual taxpayer and also a legal entity/ corporation.

\section{REFERENCES}

Andrisman, T. (2009). Asas-asas dan Dasar Aturan Hukum Pidana Indonesia. Bandar Lampung: Universitas Lampung.

Arief, B. N. (2001). Masalah Penegakan Hukum dan Kebijakan Penanggulangan Kejahatan. Bandung: PT. Citra Aditya Bakti.

Bohari, H. (2004). Pengantar Hukum Pajak. Jakarta: PT. Raja Grafindo Persada.

Chazawi, A. (2011). Pelajaran Hukum Pidana. Jakarta: PT. Raja Grafindo Persada.

Devano, S., \& Rahayu, S. K. (2006). Perpajakan: Konsep, Teori dan Isu. Jakarta: Kencana.

Kusumo, B. A. (2009). Sanksi Hukum di Bidang Perpajakan. Jurnal Wacana Hukum, 8(2), 104. doi:http://dx.doi.org/10.33061/1.jwh.2009.8.2.316

Wibowo, T. (2009). Efektivitas Sanksi Pidana Pajak dalam Undang-Undang Nomor 28 Tahun 2007 tentang Ketentuan Umum dan Tata Cara Perpajakan (Studi di Pengadilan Pajak Jakarta). Jurnal Dinamika Hukum, 9(3), 243-250. doi:10.20884/1.jdh.2009.9.3.231 